Newfoundland and Labrador Studies

\title{
Heidi Wicks. Melt
}

\section{Nathan Elliott}

Volume 36, numéro 1, 2021

URI : https://id.erudit.org/iderudit/1082224ar

DOI : https://doi.org/10.7202/1082224ar

Aller au sommaire du numéro

Éditeur(s)

Faculty of Arts, Memorial University

ISSN

1719-1726 (imprimé)

1715-1430 (numérique)

Découvrir la revue

Citer ce compte rendu

Elliott, N. (2021). Compte rendu de [Heidi Wicks. Melt]. Newfoundland and

Labrador Studies, 36(1), 162-164. https://doi.org/10.7202/1082224ar d'utilisation que vous pouvez consulter en ligne.

https://apropos.erudit.org/fr/usagers/politique-dutilisation/ 
Heidi Wicks. Melt. St. John's: Breakwater Books, 2020.

ISBN 978-1-55081-824-6

The end of the nineteenth-century marriage plot was where the politics were laid bare. Jane Austen the democrat suggests at the end of Persuasion that navy officers are now - at the conclusion of the Napoleonic Wars - eligible marriage partners, even if they were to be scorned as new money before. Indeed, some navy veterans - now appropriately rich - may even be better than your indebted, foppish aristocratic father. It's time to pay less attention to blood, more attention to cash in the bank and the genuine masculine energy of selfmade men. At the end of Anthony Trollope's Can You Forgive Her? Glencora and Plantagenet move towards a sexual resolution inside what was, until then, a childish and childless marriage. He learns that his national duty might be to his marriage bed as much as to Parliament. Austen's greatest fan had learned his mentor's lesson well: the domestic is the political. Charlotte Brontë not so subtly symbolically castrates Mr. Rochester at the end of her second novel — and in doing so grants Jane Eyre the complete domestic control she clearly has needed since she confronted the phallic Mr. Brocklehurst at the beginning of the novel. My favourite might be North and South: Elizabeth Gaskell's resolution between her characters Margaret Hale and John Thornton draws together an opinionated and beautiful woman with a handsome and taciturn man, England's agrarian south to its industrial north, even union members with their employers. The sex that came after the last page united so many polarized opposites, I like to think, must have been incredible.

I was reminded of these plots reading Heidi Wicks's Melt, in part because the author throws a few references to them occasionally; her characters read, and when they do read, they read Austen and the Brontës as well as Anne of Green Gables and Simone de Beauvoir. But these precedents also came to mind because teacher Jess and CBC radio host Cait - our central St. John's heroines — are both having marriage problems: Jess finds that her marriage to Dan has gone flat 
after her mother has died. Cait's marriage to Jake has been in trouble for some time. Soon after the opening funeral scene, Cait moves out of the home she was sharing with Jake and her young daughter. An old high school flame of Jess's moves back to the island, and Jess finds herself tempted. Throughout the novel's sexual adventures and misadventures, the real lifelong romance is between Jess and Cait and the novel's resolution is only possible with their reconciliation.

The novel's politics can be located in its temporal settings of economic upheaval and austerity. The more recent action takes place in 2016, the year of a particularly disastrous Newfoundland and Labrador budget. Numerous flashbacks take us back to when Cait and Jess were teenagers in the 1990s and the cod moratorium had begun its wretched work of reshaping the Newfoundland economic landscape and recoding its social mores. In one of the best scenes of the novel, Cait the CBC host presses the finance minister on the government's 2016 decision to savage Newfoundland's present in the name of its future and Jess calls in to the show. After the triumph of the plot to put pressure on a smarmy government official, Cait is laid off from her job. For decades now, austerity economics has always had the last laugh.

Melt is thoroughly enjoyable. The romantic ups and downs of our central protagonists are quite satisfying, if a bit predictable. The real narrative meat of the novel comes in the two women's lifelong relationship, and the novel's best dialogue comes when they are speaking to one another, rather than with their various romantic partners. As a Gen Xer forced to move my family off the island after the 2016 budget, I appreciated that my generation's story - a story all too common across North America and Western Europe - forms the background of these love stories. So many educations, careers, and sex lives have played out against a steady drumbeat of budget cuts, unemployment, underemployment, and other forms of generational economic terrorism and environmental neglect. We've been sacrificing for the future well into our middle age with no relief in sight, even as the wealthiest of the wealthy watch yet another stock market bubble inflate their bank accounts, confident and secure that purchased 
governments will cushion the eventual blow and provide safe tax havens for any plunder.

If there's a weakness in Melt, it's that the novel doesn't do more to weave these political instabilities into the romantic storylines. Jane Austen, Elizabeth Gaskell, and Anthony Trollope understood that sex is always informed by economic fortune and political intrigue. More recently, Anne Enright played the same cards in The Forgotten Waltz, a great novel about infidelity and the 2008 real estate crash. And the labour-minded films of Kelly Reichardt, John Sayles, Robert Altman, and Ken Loach are arguably Austen's, Gaskell's, and Trollope's true latter-day inheritors rather than the lavishly costumed adaptations that we see on Netflix and the BBC. Melt, at its best, reminded me of Sunshine State and Certain Women, but the novel's excellent political instincts didn't seem to inform the protagonists' ultimate sexual choices. When Cait loses her job, she briefly worries about supporting her daughter as a single mother. That potential narrative tension is never quite mentioned again. Jess's dalliance has little to do with economic storms past or present. The novel's conclusion suggests that if Jess and Cait's sex lives are satisfying, who cares about the money, closed libraries, a decapitated press, or ballooning classroom sizes? That might not be the answer a lot of us can accept in the current political and economic moment.

Still, any novel and any novelist that can remind me of Reichardt and Sayles and Enright have definitely earned my respect; I will be looking for Wicks's next novel eagerly. Generation X's story needs to be brought out of the 1980s, when John Hughes briefly gave our alienation a voice, and before we were eventually swallowed whole by the ocean of economic, demographic demand that the Boomers and the Millennials represent. Wicks has proved that she may well be up to the task - I look forward to seeing where she goes from here.

Nathan Elliott 